\title{
THE COMMUNIST PARTY CONTROL OVER THE KHARKIV TRADE UNIONS IN THE 1920S OF THE XX CENTURY
}

\author{
Sergiy Redka ${ }^{1}$, Anna Islamova ${ }^{2}$, Lesia Borzilo ${ }^{3}$, Iryna Shelukhina ${ }^{4}$ \\ ${ }^{1}$ Department of Ukrainian Studies, School of Philosophy, V. N. Karazin Kharkiv National University, Kharkiv, Ukraine \\ redka5555@gmail.com \\ ORCID: http://orcid.org/0000-0001-5960-1968 \\ ${ }^{2}$ Member of the Bucha City Council, Lviv University of Business and Law, Lviv, Ukraine \\ kharkov@htek.com.ua \\ ORCID: http://orcid.org/0000-0002-6385-1801 \\ ${ }^{3}$ Kharkiv College of Trade and Economics of Kyiv National University of Trade and Economics, Kharkiv, Ukraine \\ lesyabozr28@gmail.com \\ ORCID: http://orcid.org/0000-0002-5181-9839 \\ ${ }^{4}$ Cycle comission of food technologies and hotel and restaurant business, Kharkiv College of Trade and Economics of Kyiv National \\ University of Trade and Economics, Kharkiv, Ukraine \\ sheluhinairuna@ukr.net \\ ORCID: http://orcid.org/0000-0001-6759-2045
}

ARTICLE INFO

Article history:

Received date 13.05 .2020

Accepted date 18.06.2020

Published date 30.06 .2020

Section:

Communication Studies

D O I

$10.21303 / 2313-8416.2020 .001345$

KE Y W ORD S

trade unions

communist party

control

Kharkiv region

\section{ABSTRACT}

Object of research: trade unions of Kharkiv region as a component of the institutions of the political system of Ukraine.

Investigated problem: the growing influence of the party organization in the Kharkiv region on trade unions.

The main scientific results: the party organization of Kharkiv region controlled the local trade unions. Their personnel policy was determined in party committees. The issue of the trade union movement was decided at the bureau of the province committee. The consequence of the party leadership by the cadres of the unions was that they did not fulfill their main task of protecting the economic interests of the working people. The result of the party leadership of the Kharkiv trade unions was that they performed uncharacteristic functions. The meetings of the Presidium of the Unions discussed a wide range of issues, most of which were not directly related to the economic protection of their members.

The scope of practical use of research results: determined by suitability for use in the field of the modern state formation by politicians, parties, public organizations, state institutions, and the media.

Innovative technological product: on the basis of numerous archival materials, many of which are introduced into scientific circulation for the first time, a significant gap has been filled in the ideas about the process of party leadership of trade unions at the regional level, namely in Kharkiv region.

The scope of the innovative technological product: the practice of forming, implementing and improving the system of state regulation by public organizations.

(C) The Author(s) 2020. This is an open access article under the CC BY license http://creativecommons.org/licenses/by/4.0).

\section{Introduction}

\section{1. The object of research}

Trade unions of Kharkiv region as a component of the institutions of the political system of Ukraine.

\section{2. Problem description}

In modern conditions, the activity of trade unions, which are called upon to ensure the protection of the rights and interests of the working man being, is gaining importance. This is a consequence of the weakness of the Ukrainian trade unions, their lack of effectiveness, and even the negative perception of the trade unions by society, poor motivation; and lack of competence of trade union personnel. Ukrainian society has not yet overcome the authoritarian style of relations between the bearers of power (political and economic) and ordinary members of society. Moreover, this style is reinforced, despite the democratic transformations. 


\section{3. Solution to the proposed problem}

In Ukraine, unions do not fulfill their assignment. They see the solution to their problems not in improving performance, but in strengthening state guarantees. Lack of proper control over the work of the employer is the main reason for the inability of trade unions to solve the social and labor problems of the enterprise. In addition, many employees are not covered by trade union influence, especially in the semi-illegal and illegal sectors. Today, the employee in these sectors is left face to face with the employer, who, not bound by certain restrictions, including moral ones, can do arbitrariness: pay low salaries, do not provide necessary social conditions, to allow overexploitation of the employee. Therefore, there is no doubt that unions should become a strong player in protecting the rights of people of wage labor. In our opinion, the weakness of modern Ukrainian trade unions is due to the fact that for a long time they were obedient executors of the will of the communist party bodies, and now they remain dependent on the will of the enterprise administration.

The aim of research is to reveal the mechanism and specifics of the influence of party committees in the region on the current activities of trade union organizations in the 20s of the XX century.

\section{Materials and methods}

The methodological basis of research is a system of scientific principles, approaches and methods of cognition aimed at a comprehensive study of socio-political phenomena, facts and events, objective reproduction and analysis of historical realities. The work is based on the fundamental principles of scientific knowledge of: historicism, objectivity, a critical analysis of dialectics, systematic, comprehensive, alternative, etc.

\section{Results}

After October 1917, the Bolsheviks did not yet have a monopoly influence on the trade unions. At the beginning of January 1919, a number of Kharkiv trade unions at such enterprises as KhPZ, (Kharkiv steam engine plant), VEC ( All-Russian Electric Company), and HelferichSade were controlled by the Mensheviks [3, arch. 15]. The Mensheviks restored the legal trade union centers of the Bureau of the South of Russia in Kharkiv, which considered their main task the restoration of trade unions independent of the authorities. Despite the persecution by Denikin's, the trade union centers in Kharkiv and Kyiv acted more independently than ever before [4, p. 179]. The Mensheviks considered the main task of the trade union movement to maintain its independence from the dominant Bolshevik party. With the return of the Red Army, the Communist Party used all the levers of power to eliminate the influence of the Mensheviks on the trade union movement. In particular, the leadership of the Kharkiv Central Council of Trade Unions, which was influenced by the Mensheviks, was liquidated. The Bolsheviks could not forgive the RSDLP not for cooperation with Denikin in the trade unions, but for the very existence of the trade unions under the leadership of the Social Democrats and criticism of the policies of the Communist Party on their part, distracting workers from it. The monopoly on power allowed the Bolsheviks to use any means in the struggle for influence on trade unions. But the power of the Communists was not yet so strong as to begin total mass actions against the Mensheviks, which in the early 1920s in Kharkov had quite a strong influence on the professional movement, despite the oppression. They held strong positions at the Melgose and Shpilberg factories, at the 1st and 3rd cloth factories [5, p. 43-44]. The First All-Ukrainian Congress of Trade Unions, which took place in April 1921, sharply criticized the Mensheviks for trying to divert the attention of workers from the political struggle for Soviet power and for trying to oppose the trade unions to the Soviet state. The congress expressed no confidence in the Menshevik leadership and ruled to liquidate its governing body to Utsentroprof. The main goal of the congress was achieved: the Mensheviks were removed from the leadership, the trade unions integrated into the party-political system, undeniably fulfilling all its orders [2, p. 30].

At the beginning of 1921 in the Kharkiv region, the trade union organization numbered 140, 8 thousand members [6, p. 299]. The Bolsheviks could not leave the mass organization, the number of which grew rapidly without their influence. After the First Congress of Trade Unions, the process of their bolshevization on the local level began, which included the removal of the Mensheviks, the dissolution and controlled elections of objectionable unions, the re-registration of members with simultaneous purges. During its conduct, non-labor elements and enemies of the Soviet gov- 
ernment were excluded. By September 1922 the number of trade union members was reduced by $1 / 3$ compared with the beginning of the year [7, p. 197]. The congress also adopted a resolution on the full support of the Soviet government, on the transformation of trade unions from organs of the economic struggle to organs of socialist construction. In March 1922, as already noted, the DPU (secret political service) liquidated the Main Committee of the RSDLP in Ukraine and the Kharkiv provincial committee. After this blow, the Mensheviks stopped working in the trade unions. During the time of the "counter-revolutionary governments", they legally acted in trade unions. With the establishment of the "dictatorship of the proletariat", the Mensheviks - the party of the working class - were forced to recall the means of illegal activity from the time of tsarist autocracy. They were declared the "vanguard of the whole reaction".

In the first months of 1921, the Central Committee of the Communist Party(b)U mobilized 506 communists for leadership in the trade unions, and 200 in the provincial committees. During the same period, the Central Committee of the RCP (b) sent 623 communists to Ukraine for union work [7, p. 197-198]. According to the resolution of the bureau of the Kharkiv provincial committee of August 31 duty journeys of party members to work in the provincial trade union bodies were carried out exclusively by the a provincial committee. Duty journeys by the relevant central trade union bodies were allowed only by agreement with the Provincial Committee through the Central Committee. There could also be no business trip for the permanent work of the provincial trade unions in the county without the sanction of the provincial committee party [8, p. 14].

Important decisions regarding trade unions were made at the IX Congress of the RCP. The resolution of the congress noted that the trade unions were only formally non-partisan, but in fact they became communist and pursued the policy of the Communist Party. "Only to this extent is the victory of the dictatorship of the proletariat and the building of socialism ensured" [9, p. 255]. In the future, the party has consistently acted in accordance with this statement, using trade unions as a tool of its own policy. It was also noted at the congress that the party leadership by trade unions should have been carried out through communist factions. Each faction was subordinate to the party committee. And the VCRPS (All-Union Central Council of Trade Unions) faction was subordinated to the Central Committee of the RCP (b). Decisions of the All-Union Central Council of Trade Unions could be canceled by the Central Committee of the RCP. Local committees CP(b)U were supposed to direct the ideological work of the trade unions and not engage in their petty care. Relations between them should have been regulated by the Party Charter. But the party did not always exert ideological influence on trade unions through fractions, but also directly intervened in their activities. At a meeting of the bureau of the Kharkiv Provincial Committee dated December 3, 1924, the report of the Kharkiv Provincial Council of Trade Unions (hereinafter referred to as the KhGRPS) "On the mass work of trade unions" noted: "The method of managing the GRPS was reduced to personal calls and visits to the GRPS, participation in the construction of governing bodies, reporting GRPS at congresses and conferences [10, p. 6]. The issue of the trade union movement was worked out at the bureau of the Provincial Committee, the Communists participated in congresses and conferences of trade unions [10, p. 1]. The Bureau of the Provincial Committee approved the KhGRPS annual work plan [11, p. 28]. Party bodies could even liquidate a union [11, p. 41]. The leadership was carried out through the factions, but the decisive word was for the party committee of the appropriate level. For example, trade union reports were approved by the party's provincial committee [11, p. 4].

The influence of the party on public organizations through fractions in them could be considered democratic, but provided that there are several parties in society and not one of them has a monopoly on power. In Ukraine, after 1922, almost no one competed with the Communist Party. It ruled solely. Therefore, party leadership by public organizations through factions did not comply with democratic standards.

In democratic societies, the main tasks of trade unions are related to the exercise of their functions - protecting the rights and interests of workers in the field of labor and labor-related relations. It is for this purpose that trade unions arose, for this purpose workers united and unite in them voluntarily in accordance with their interests and sphere of activity to protect the labor, social and economic interests of their members.

The independence of trade unions is the first of the basic principles that is ensured by the direct prohibition of any interference by state authorities and officials in their activities, is ensured 
by property independence, the right to develop and approve their charters, determine the structure, elect governing bodies and so on. But unions did not have independence. Their personnel policy was determined in party committees. In protocol No. 39 dated January 6, 1922, meetings of the bureau of the Kharkiv Provincial Committee party approved candidates for the Presidium of Union Trade Unions [11, p. 4]. In the minutes No. 45 of the meeting of the bureau of the Kharkiv Provincial Committee on January 23, 1922 it was noted: "To finally confirm Comrade O. Medvedev as the KhGRPS chairman. At the nearest plenum of the province committee, to co-opt Comrade A. Medvedev in the province party committee and the presidium of the province committee" [11, p. 14]. Formally, the party struggled with the appointment of governing bodies in the unions. In Minutes of the meeting of the bureau of the provincial committee in the resolution on mass trade union work on it was noted in the village that in order to raise the authority of trade unions before ordinary members and revival of their activities need to strengthen holding of the elections of the trade unions at the general meeting, to refuse to impose elected candidates unwanted by the union members. Condemned practice by local party cells on frequent change of elected trade union workers [12 p. 87]. And in practice, even the head of the Kharkiv GRPS he appealed to the provincial committee of the party with a statement about the need to send in orders of the KhGRPS of eight party workers to replace the various post. The organizing department was instructed to choose [11, sheet 20]. Provincial Party Committee decided when to give vacation to the chairman of the Kharkiv trade unions, who will be to replace it at that time [11, sheet 94; 216, p. 177]. Candidates for trade union leadership positions were nominated at factories party cells. Secretary of the Chervonozavodsky District Party Committee M Mukle in his report to the Kharkiv District Party Committee, he noted that under time of elections to trade unions at KhPZ in the vast majority were candidates, outlined cells $[13$, p. 83]. In the Political report of the plant cell "Sickle and a hammer" for April, 1928 it was specified that Candidates for the factory trade union committee were put forward by cells. They were elected. The workers showed indifference. They say that the head committee still does not benefit, they protect the line state enterprise administration [13, sheet 68]. There were cases when candidates nominated by party committees for the factory committee did not pass. These cases in the party were considered as insufficient cohesion of the Communists [13, p. 10]. In the report of the communal workers for the first half of 1927, the case of nominations by a group of members of the union was regarded as an example of poorly done preparatory work [14, p. 72]. If union members nominated a candidate independent from the party bodies they could not be elected under a contrived pretext. In particular, the Kharkiv Proletarian newspaper stated that a trade union member was not elected to the board because he was a homeowner and his daughter was married to a White Guard General. The former White Guard officer also does not elected. The candidate who had previously traded in the bazaar was not elected. Party committees did not miss their attention to such an aspect as the approval of the characteristics of the workers of trade unions [11, p. 115].

The consequence of the party leadership of the cadres of the trade unions was that they did not fulfill their main task of protecting the economic interests of workers. Already in June 1920, at a meeting of the Kharkiv Provincial Trade Union when considering a strike of textile plant workers in New Bavaria (district of the Kharkiv town), it was decided: no payment should be made, because the strike was caused by "the presence of a non-proletarian element in the factory". Department of the labor was instructed to "take measures to remove him" [2, p. 31]. In a political letter from Ivanovsky District Party Committee from 01.06. on September 1, 1928, it was said: "Top Secret. The workers are sharply dissatisfied with the unions, which poorly help them in raising salaries" [13, p. 58]. The political power of Chervonozavodsky District Party Committee for June 1928 gave examples of dissatisfaction with the work of unions, defended the interests of enterprise administrations, and not their members [13, p. 18].

In conditions when, as a result of incompetent economic policy, the state found itself in a crisis, trade unions, on the contrary, helped to reduce wages and raise production rates. They referred to the fact that throughout industry there was a decrease in labor productivity, a reduction in financing, shortages in the supply of raw materials, its poor quality, and deterioration of equipment [15, p. 4]. In a secret political report from the Sickle and Hammer plant in February 1928 states: "The whole month passed under the sign of leveling the salary. For this purpose, plenums of the factory committee were held" [13, p. 68]. They also said that at the VEK plant P. Postyshev, executive secretary of the Kharkiv district committee of the Communist Party of the Bolsheviks 
of Ukraine, having entered the chipping shop and seen what working conditions are there, noted that it is not necessary to reduce salary, but they were still reduced" [13, p. 68]. Workers complained: "Now, they exploit us more than before. What kind of worker-peasant power is this? We barely make ends meet. Trade unions are on the side of the administration but do not protect workers" [13, p. 68]. In general, the trade union only supported the decisions taken by the party bodies for regulating wages and labor standards. Under District Party Committee, a commission was established to review labor rates and salary. It led this campaign through the district committees and the faction of unions [16, p. 11].

Trade unions did not defend the interests of workers either in collective bargaining. At a meeting in the Kharkiv Provincial Committee on June 10, 1924, on the results of the GRPS campaign for collective agreement, it was noted: "It should be noted that the campaign reduced the salary fund to a certain extent, as well as streamlined the issue of charging" [10, p. 1]. The resolution on the report of the Presidium at the II Plenum of the Kharkiv districts of trade unions in May 1926 noted that there were cases when economic bodies did not comply with collective bargaining points and the trade unions did not respond to this [15, p. 29]. Trade unions acted more on the side of the state than on the side of their members. A February 1929 report by the District Council of Trade Unions on a collective agreement company stated: "I had to convene conferences two times and explain the unacceptability of workers' demands. The unions paid little attention to the general political challenges and difficulties facing the industry" [17, p. 184].

The activities of trade unions did not meet the principle of protecting the interests of all workers. Socially alien and objectionable elements were excluded from its members. The report of the unions of the Kharkiv District Trade Union Council for May-October 1927 states: "3 members of the union are excluded - one relative of the artisan, two - relatives of the private owner" [14, p. 4]. In the first half of 1927, former members of the cult and former gendarmes, persons with criminal records were expelled from the Southern Railway Trade Union [14, p. 33] Trade union members who were deprived of voting rights, could also be expelled from unions [18, p. 8].

As a result of such party leadership, the trade unions were engaged in inappropriate functions. The breadth of the tasks of trade unions is evidenced by their organizational structure. The factory committee had the following sectors: organizational, informational, cultural, agitation, wages, social services, supply, residential, labor protection, public catering, engineering and technical sectors, and the bureau of voluntary unions. The trade unions were engaged in improving the Soviet apparatus that participated in its cleaning, mobilized the working masses to combat bureaucracy, and engaged in the collectivization of agriculture [19, p. 503, 527, 530]. During the period of mass collectivization, the party completely laid on the trade unions the organization of sponsorship of the working class to the peasantry [7, p. 269]. G. Zinoviev, speaking at the VI Congress of Trade Unions, set them the task - to increase labor productivity [20, p. 25].

The party had the idea that the trade unions should fight against downtime and shortages, be interested not only in their machine tool, brigade and workshop, but also in the workshops and factories that supply their enterprise with raw materials, fuel and so on. They should connect the specific needs of workers with the interests of socialist industry [21, p. 223]. That is, the unions were tasked with managing the economy. M. Tomsky, chairman of the USSR trade unions, considered it impossible to participate in the management of production and protect the interests of the proletariat. He was accused of distorting the party's policy and contrast the protection of the material interests of the working class to the interests of socialist industry. The defeat of the leadership of the All-Union Central Council of Trade Unions, led by M. Tomsky, was carried out under the pretext of combating trade unionism, which in essence was the protection of the daily interests of workers.

A wide range of issues was also discussed at a meeting of the Presidium of the Kharkiv Regional Trade Union: tractor construction, provision of meat and bread to the population, reorganization of local industry, draft law on rents, elimination of unemployment, and collection of funds for English miners on strike. The trade unions fought to increase labor productivity and the cultural level of the masses, lower prices, and implement party and Soviet decisions regarding the economy. At meetings of the Presidium of the Kharkiv Regional Council of Trade Unions for June-December 1927, 607 questions were considered (the author calculated). All these issues, in our opinion, did not directly concern the economic protection of union members [22]. 
An important place in the work of trade unions was held in the elections to the soviets. They hung lists, posters, prepared reports, spent evenings, arranged book exhibitions, and organized libraries. Other party directives on the organization of elections were fulfilled [14, p. 32].

Trade unions even performed administrative and punitive functions at the provincial congresses of Kharkiv in February and December 1920. They pledged to use coercive means in workers in the interests of production. In the minutes of the meeting of the bureau of the province committee for 1925 it was noted: "It is necessary to stop the performance of administrative functions by trade unions - tax collection, searches, administrative pressure on peasants, which occur in the practice of trade unions" [12, p. 87].

With the coming to power, the Communists began the process of Bolshevization of local unions, which included the removal of the Mensheviks from their ranks, the dissolution and controlled elections of objectionable unions, the re-registration of members with simultaneous purges. The organizational structure of trade unions was also changed. Union leadership has shifted from a territorial principle to a centralized one. Associations of trade unions on an all-Ukrainian scale are conducted, which contributed to the party leadership.

The activities of trade unions did not meet the principle of protecting the interests of all workers. Socially alien and objectionable elements were excluded from its members. In democratic societies, the main tasks of trade unions are related to the exercise of the function of protecting the rights and interests of workers in the field of labor and labor-related relations. Their independence is the first of the basic principles of activity. But then the trade unions did not have independence, but were completely controlled by the party.

\section{Discussion}

A significant amount of literature has been issued on the issue under study, but it appeared in most of the mid-80s and received the ideological influence of past years. Interpretation of certain events is presented in it within the framework of officially approved approaches and concepts. The literature was dominated by a unanimous positive assessment of the activities of trade unions as a school of communism, ruled by the communist party. After the creation of the Ukrainian state, the role of trade unions is served from a new perspective. There is literature where it is alleged that trade union bodies have become obedient executors of decisions of party committees. The main purpose of the trade unions is to protect the economic and social interests of workers, were thrown into the background, and replaced by a task not characteristic of trade unions $[1,2]$.

The results of the study can be used by historians, political scientists and other specialists for further research on the phenomenon of totalitarianism in the USSR and Ukraine. Materials and conclusions of the study can be used to create works summarizing the history of political, social, national and cultural development of Ukraine, to prepare scientific papers, teaching and methodological aids, and to create special courses on the problems of the trade union movement.

The practical significance is determined by the suitability for use in the process of modern transformation of the trade union movement by politicians, parties, public organizations, state institutions, and the media. This will help accelerate the process of overcoming the totalitarian heritage and post-totalitarian tendencies of Ukraine, and will help create free trade unions capable of effectively protecting the rights of their members. Such as it happens in democratic countries, where trade unions are independent public organizations and defending the interests of their members.

\section{Conclusions}

1. As a result of the party leadership, the trade unions in the 20 s of the XX century, of the Kharkiv region performed functions uncharacteristic of them that did not relate to the protection of workers' rights.

2. Personnel policy was determined in party committees, and not through elections of leading trade union bodies.

3. Local organizations and ordinary members of trade unions had no influence on trade union affairs.

4. Trade union did not protect the rights of workers, but rather the interests of the state. 
Structures of the $\mathrm{CP}(\mathrm{b}) \mathrm{U}$ in the Kharkiv region controlled the local trade unions by determining their personnel policy by the relevant party committee or party cell organization in the workplace. When didn't elect candidates, which was appointed by the party leadership, it was seen as a failure in the work of the party cell and had corresponding organizational consequences for party members. Forcing trade unions to perform uncharacteristic ones, in particular administrative and punitive ones functions, participation in political and ideological campaigns became a reality daily practices of party cells at all levels.

\section{References}

[1] Protokoly zasidannia biuro hubkomu KPbU. Protokoly obiednanoho zasidannia hubkomu, Sumskoho povitovoho komitetu partii ta Prezydii hubernskoho vykonavchoho komitetu. 10.06.1919-29.12.1919. DAKhO, F. 1, Op. 1, Spr. 2, 12.

[2] Holikova, O. M. (2000). Menshovyky v Ukraini u roky revoliutsii i hromadianskoi viiny (1917-1920 rr.). Kharkiv, 233.

[3] Protokoly zasidan Prezydii, biuro ta plenumiv komfraktsii miskrady. Protokoly komisii po kerivnytstvu kampaniieiu pro perevybory do miskrady. Biuleteni pro khid perevyboriv. Skhema orhroboty miskrady ta polozhennia pro prava ta oboviazky chleniv miskrady 12.02-30.12.1921. DAKhO, F. 1, Op. 1, Spr. 575, 40.

[4] Antonova, V. G. (Ed.) (1999). Ocherki istorii profsoiuzov KHarkovschiny. Kharkiv: Tornado.

[5] Chornyi, D.; Posokhov, S. I., Astakhova, K. V., Kudelko, S. M. et. al. (Eds.) (2014). Kharkivski hubernski profspilky. Kharkivshchyna: Entsyklopedychnyi slovnyk. Kharkiv: Zoloti storinky.

[6] Babkov, Iu. V., Vargatiuk, P. L., Goshuliak, I. L. et. al. (1983). Ocherki istorii professionalnykh soiuzov Ukrainskoi SSR. Kyiv: Politizdat Ukrainy, 664.

[7] Protokoly zasidan komunistychnoi fraktsii hubvykonkomu ta lystuvannia z neiu 05.06.1922-06.11.1922. DAKhO. FR. 203, Op. 1, Spr. 632, 48.

[8] Egorova, A. G., Bogoliubovoi, K. M. (Eds.) (1983). KPSS v rezoliuciiakh i resheniiakh sezdov, konferencii i plenumov CK (1898-1986). Vol. 2. 1917-1922. Moscow: Politizdat, 606.

[9] Protokoly narad pry orhinstri hubpartkomu. Plany roboty hubpartkomu 20.04.-03.12.1924. DAKhO, F. 1, Op. 1, Spr. $1106,27$.

[10] Protokoly zasidannia Kharkivskoho hubkomu KP(b)U z 2 sichnia po 28 hrudnia 1922 roku. DAKhO, F. 1, Op. 1, Spr. $719,148$.

[11] Protokoly zasidan biuro hubkomu ta dodatky do nykh 19.03-22.10.1925. DAKhO, F. 1, Op. 1, Spr. 1140, 220.

[12] Politychni zvity, lysty, zvedennia vid partiinykh orhanizatsii zavodiv mista 23.02.1928-28.12.1928. DAKhO, F. 5, Op. 1, Spr. 43, 95 .

[13] Zvity spilok okrprofrady Kharkivskoi okruhovoi profrady. Traven-zhovten1927roku. DAKhO. FR. 1392. Kharkivska okruhova rada profspilok m. Kharkiv 1927-1930 rr. Op. 1, Spr. 3, 241.

[14] Protokoly zasidan plenumiv ta prezydii Kharkivskoi okruhovoi rady profspilok 24.01-25.12.1926. DAKhO, FR. 1392, Op. 1, Spr. 29, 75.

[15] Protokoly zasidan reviziinoi komisii Kharkivskoho okruhovoho komitetu ta materialy do nykh. Zhovten-hruden 1928 r. DAKhO, F. 5, Op. 1, Spr. 41, 76.

[16] Protokoly zasidan biuro Kharkivskoho okruhovoho partkomu z 13 po 14 liutoho 1929 roku ta materialy do nykh. DAKhO, F. 5, Op. 1, Spr. 48, 213.

[17] Materialy pro diialnist Kharkivskoi okruhovoi rady profspilok. Postanovy, zvity, lystuvannia 08.01.1925-19-12.1926. DAKhO, FR. 1392, Op. 1, Spr. 106, 256.

[18] Bataevoi, T. V. (Ed.) (1963). Profsoiuzy SSSR: dok. i materialy : 1905-1963. Vol. 2. Profsoiuzy v period postroeniia socializma v SSSR, oktiabr 1917 g. - 1937 g. Moscow: Profizdat, 867.

[19] Zinovev, G. (1925). Profsoiuzy i nashi zadachi: rech na otkrytii Vsesoiuz. sezda profsoiuzov ot 11 noiabria 1924 g. Moscow; Leningrad: GIZ, 40.

[20] Profsoiuzy v borbe za socializm: doklady i rezoliucii (1932). Voronezh: Kommuna, 297.

[21] Protokoly zasidan prezydii Kharkivskoi okruhovoi rady profspilok 03.06-30.12.1927. DAKhO, FR. 1392, Op. 1, Spr. $123,106$.

[22] Movchan, O. M. (2004). Ukrainski profspilky v kompartiino-radianskii systemi vlady (1920-ti rr.). Kyiv, 35. 